\title{
Hosting multinationals: Economic and fiscal implications
}

\author{
Peter Egger and Marko Koethenbuerger ${ }^{1}$ \\ ETH Zürich and KOF
}

\begin{abstract}
Switzerland is a prime location for both domestically owned as well as foreign-owned multinational enterprises (MNEs). In this paper, we review the literature on MNE activity with respect to its main fundamental (non-policy) drivers, the non-fiscal consequences of MNEs for various economic aggregates, and the fiscal implications associated with the operation of foreign affiliate networks. In particular, the paper puts emphasis on the fiscal implications of hosting MNEs and their relation to the current tax environment in Switzerland.
\end{abstract}

JEL codes: $\quad \mathrm{H} 25, \mathrm{D} 21, \mathrm{~F} 23$

Key words: $\quad$ fiscal competition, multinational firms, globalization, corporate tax avoidance

\section{Introduction}

Switzerland is a prime location for both domestically owned as well as foreignowned multinational enterprises (MNEs) for three major reasons: (i) it has abundant skilled labor and physical capital, both of which are intensively used by MNEs; (ii) while being a small market itself, it has a high market potential accruing to its location in the center of the European continent and its accessibility via major transport routes (air, rail and road); and (iii) the market access costs are small in Switzerland and the economic-political environment is favorable towards the operation of domestically or foreign-owned large and highly profitable enterprise networks.

Besides the economic factors that attract firms, Switzerland offers a competitive level of corporate taxation. The general level of corporate taxation was roughly $23 \%$ in 2013 , which is lower than the ordinary rate of corporate tax in most core European countries. Moreover, Switzerland offers special tax regimes to certain types of MNEs. These special tax regimes significantly reduce the corporate tax burden, which, following their implementation, has led to a large inflow of subsidiaries and headquarters of MNEs to Switzerland. Tax revenues of tax-privileged firms have grown significantly in the last decade and nowadays constitute a major source of tax income at the cantonal and federal levels of government. The special tax regimes have been repeatedly criticized by the OECD and the EU because of their discriminatory nature. Switzerland is currently reforming its tax system by replacing the special tax regimes with

1 We are grateful to conference participants at the University of St. Gallen for their comments on the paper. In particular, we are grateful for valuable comments by our discussant Christian Keuschnigg 
new tax instruments that do not discriminate between multinational and domestic firms, but continue to offer a competitive level of corporate tax to MNEs.

The goal of this paper is to review the literature on MNE activity with respect to its main fundamental (non-policy) drivers, the non-fiscal consequences of MNEs for various economic aggregates, and the fiscal implications associated with the operation of foreign affiliate networks. We also discuss the fiscal implications of various tax reform proposals for Switzerland, such as the introduction of a licence box.

\section{Economic reasons for and implications of hosting MNEs}

\subsection{Economic fundamentals of the emergence of MNEs}

Economic theory distinguishes between three broad types of MNEs: horizontally organized MNEs produce one and the same product in all plants, whether at home or abroad (MARKUSEN, 2002); vertically organized MNEs disentangle (unbundle) production stages along a vertical dimension and produce the individual stages wherever it is relatively cheapest, which eventually entails intra-firm trade (MARKuSEN, 2002); and export-platform MNEs organize their production in a horizontal way but also serve third markets through exports from specific plants (EKHOLM, FORSLID and MARKUSEN, 2007).

There are considered to be three fundamental drivers behind the emergence of MNEs: relative market size and market potential (i.e. host-market plus thirdmarket size); relative production costs across markets; and relative market access costs (e.g. costs associated with exporting to a market versus setting up a foreign affiliate there). The effects of these fundamentals on MNE activity are as follows. First, larger markets or countries with greater market potential make the setting up of foreign affiliates ceteris paribus more profitable, since the fixed costs of setting up a foreign plant can be more easily covered. Second, relatively cheaper production costs (due to the greater productivity of MNEs as such, the greater productivity of factors in a country, or the cheaper factor costs in a country, for example) make setting up a foreign affiliate relatively cheaper than exporting, especially if trade costs or factor costs in the parent country are high so that exporting to a market would be relatively more costly than local supply through foreign affiliates. Third, if the market access costs of MNE production (mostly associated with fixed costs from setting up a foreign affiliate) are higher than those of exporting (mostly associated with variable or fixed trade costs) - in which case, we would speak of an advantage of proximity to customers relative to the concentration of production in one plant - it would be ceteris paribus profitable to 
serve customers in a given market through local foreign affiliate sales rather than through exports. Clearly, most policy measures such as tariffs or taxes affect the latter trade-off between proximity and concentration and therefore induce a bias towards or away from MNE production.

\subsection{Important consequences of the operation of MNEs}

\subsubsection{Technology spillovers}

There is vast evidence that multinational firms induce voluntary as well as involuntary spillovers to other, local firms in host markets. These spillovers appear to be geographically bounded, mainly affecting neighborly firms. There are four main reasons for spillovers offered (though often not observed) in the literature: (i) cooperation of multinational firms with local input suppliers and associated voluntary technology diffusion to ensure that inputs meet high quality standards; (ii) research cooperation between multinational firms and other, horizontally related local firms and an associated voluntary technology diffusion; (iii) worker flows among multinational and other firms that induce involuntary knowledge dissipation; and (iv) imitation by local firms associated with involuntary technology spillovers. The evidence for such positive spillovers exists for many datasets and continents. ${ }^{2}$

The key reasons why multinational firms are special as a source of technology spillovers relative to other, domestically operating firms are as follows. First, MNEs are the proprietors of large bases of innovation pools (in terms of patents owned, for example) and they tend to be larger and more productive than smaller, domestically operating units (Helpman, Melitz and Yeaple, 2004). The technological leadership of MNEs makes it particularly beneficial for imitators to gather knowledge about their production processes, which entails involuntary technology spillovers. Second, they engage to a large extent in local sourcing and arm's-length transactions with unaffiliated units (MUENDLER and BECKER, 2010; EgGer and SEIDEL, 2013). In order to ensure the required quality of intermediate goods that are sourced from local contractors, MNEs often jointly develop products and even train contractors, with the latter entailing voluntary technology spillovers.

2 See, for example, Smarzynska Javorcik (2004) and LööF (2009) for Europe; Keller and Yeaple (2009) and Bloom, Schankerman and van Reenen (2013) for the United States; and Hu, JefFerson and Jinchang (2005), Swenson and Chen (2014), and Baltagi, Egger and Kesina (2014) for China. 


\subsubsection{Competitive effects}

As pointed out by SMARZYNSKA JAVORCIK (2004) and, in particular, by Bloom, SCHANKERMAN and VAN REENEN (2005), what is dubbed "technology spillovers" in empirical work consists in fact of two main components: the technology transmission as such, as discussed in the previous paragraph; and interdependence of prices across firms through market structure effects. Empirical work often inappropriately attributes any form of interdependence to the former and disregards the latter. In economic theory, the market entry of multinational firms is frequently associated with so-called "pro-competitive effects" (MARKUSEN, 2002). These flow from an increase in product-market competition as a result of the rising number of competitors due to the setting up of foreign plants in a given market. Since MNEs and their affiliates are often more productive than their local competitors, the market entry of MNEs may lead to larger welfare gains from foreign-owned plant entry than from domestic firm entry. Hence, apart from the welfare gains from an increase in factor demand, host countries may also benefit from foreign firm entry by getting access to cheaper products than they would through importing or through domestic firm entry. Home countries of multinational firms benefit from repatriated profits that may exceed the profits associated with serving the foreign market via trade (if the costs from the duplication of production processes in setting up a foreign plant are lower than those of exporting to the host country and the associated lower product demand).

\subsubsection{Wage effects}

With regard to the wage effects of MNEs, two aspects should be distinguished: one is the effect on wages at given skill levels, and the other is the impact on the skill composition of labor demand in MNEs relative to other firms.

It is widely acknowledged that multinational firms pay a wage premium to their workers. The literature distinguishes between observable and unobservable determinants of this premium. ${ }^{3}$ Important (more or less) observable determinants are firm productivity, the size and location of the affiliate network, the sector affiliation of the affiliate network, and the skill composition of the workforce. It appears to be the case that these observable fundamentals explain all of the multinational firm wage premium in some countries (mostly developing countries, transition countries and newly-industrialized economies) ${ }^{4}$ but not in others

3 See Aitken, Harrison and Lipsey (1996); Girma, Greenaway and Wakelin (2001); Budd, Konings and Slaughter (2005); Girma and Görg (2007); Görg, Strobl and Walsh (2007); Malchow-Møller, MARKUSEN and SchJERNING (2007); and EgGER and KreICKeMEIER (2013).

4 See Aitken, Harrison and Lipsey (1996); Te Velde and Morrissey (2003); Dobbelaere (2004); Lipsey and SJÖHOLM (2004); and HARRISON and SCORSE (2009). For evidence of a premium in industrialized countries, see Girma, GreenaWay and WaKelin (2001) and GrifFith and Simpson (2004). 
(mainly developed, industrialized countries). ${ }^{5}$ In other words, conditional on the main fundamentals of MNE operations - foremost, their productivity (EGGER and Kreickemeier, 2013) - there is no MNE wage premium. The premium on wages that multinational firms pay to workers of a given skill level, age and so on, and in a given sector and country, is fundamentally due to their greater productivity (and profitability). Clearly, this means that policies that reduce the greater profitability and productivity of MNEs relative to other firms or that reduce the incentive of MNEs to locate in a market will reduce the wage bill of workers in at least those firms, but eventually also in others (if the workforce employed in MNEs is large relative to the economy as a whole).

\subsubsection{Employment effects}

The literature on the employment effects of MNEs largely revolves around the question of how domestic employment in the location of the headquarters is affected by an MNE's foreign operation. The early literature on the matter reported that firms that produce abroad tend to have fewer employees at home to whom they pay higher wages or salaries (KRAVIS and LIPSEY, 1988), suggesting a substitution relationship between domestic and foreign labor demand within MNEs. Much of the evidence on the matter is based on the consequences of outsourcing and offshoring, which does not pertain to MNE activity alone, and which accounts for within- as well as across-firm effects (FEENSTRA and HANSON, 1999). This literature tends to find relatively large substitution (implicit) effects of foreign activity on domestic labor demand. However, the literature on the substitution versus complementary relationship between foreign and domestic labor demand is not unequivocal. For instance, Konings (2000), Slaughter (2000) and Barba Navaretti and Castellani (2004) find no evidence that MNEs' operations in low-wage locations have an impact on home-market labor demand, while Braconier and EKHOLm (2000), BrAinARD and Riker (2001), Becker and Muendler (2008), and Muendler and Becker (2010) do find evidence of a substitution relationship. Clearly, much of this evidence works under the presumption that MNEs organize their affiliate networks in a vertical way and that foreign operations more or less necessarily substitute for domestic production. Pfaffermayr (2001) alludes to the fact that the horizontal versus vertical organization of MNE networks affects the substitution between foreign and domestic employment. Moreover, some of the evidence on a substitution relationship between domestic and foreign employment holds firm output constant in a counterfactual equilibrium, so that a substitution relationship is trivially (but economically eventually inaccurately) found.

5 See Aitken, Harrison and Lipsey (1996); Globerman, Ries and Vertinsky (1994); and Almeida (2007). 


\subsubsection{Factor demand beyond workers}

Since MNEs use not only (unskilled) workers in host countries but also other factors - most importantly, skilled labor (Egger and Pfaffermayr, 2005; Bergstrand, Egger and Larch, 2010), physical capital, and intermediate products (Bergstrand and Egger, 2010; Baldwin and TAglioni, 2012) - they also induce effects on factor markets other than that for unskilled workers. Since production stages are more or less footloose (i.e. freely mobile) across the units within MNEs, the firms use skilled labor, physical capital and intermediate products wherever they are most abundant and cheapest. For instance, Switzerland, being a capital- and skilled-labor-abundant country, is a prime location for capital- and skilled-labor-intensive production stages such as research and development. To the extent that MNEs pool skilled labor from all over their foreign affiliate network and skilled labor is relatively mobile across international borders, the emergence of MNEs leads to gross flows of skilled workers and expatriates (Bergstrand, EgGer and Larch, 2010) to those locations where they can be most productively used.

\subsubsection{Effects on volatility and international shock transmission}

A more recent literature on MNEs is concerned with the transmission of shocks across affiliates within MNEs and, accordingly, into regions and sectors where MNEs are active. ${ }^{6}$ This literature points to important business-cyclesynchronization effects of the sectoral and regional (cross-country) composition of MNEs' foreign affiliate networks. Based on the finding of KLEINERT, MARTIN and Toubal (2014), one would conclude that MNE activity is a major factor in explaining the cross-regional variation in the business cycle within a country (in their case, France).

\subsubsection{Effects on governance, transparency, and corruption}

High standards of governance of political and economic systems, transparency of political decision processes, and low levels of corruption are among the most robust drivers of multinational activity and foreign plant set-up (EGGER and Winner, 2006; Egger, Keuschnigg, Merlo and Wamser, 2014). With capital being more footloose nowadays than before, this puts pressure on countries with weak governance, low transparency and high corruption as they may not be able to attract foreign capital, preventing them from access to technology spillovers, enjoying higher wages, and getting on to a higher growth trajectory (CIPE, 2009). However, in general, there is neither a hypothesis nor evidence of an

6 See Jansen and Stokman (2006); Burstein, Kurz and Tesar (2008); Hsu, Wu and Yau (2011); Kleinert, MarTin and TOUbal (2014). 
unequivocally negative impact of corruption on MNE activity. In fact, EGGER and WINNER (2005) show that, in countries with low institutional quality, corruption may grease the wheels of international commerce. Neither is the impact of MNE activity on corruption and the quality of governance clear-cut (for theoretical results on the latter, see Pierre, 2011).

\subsubsection{Effects on the environment}

There is some evidence that foreign direct investment and, hence, MNE activity (along with international trade) raises pollution at the global level, leads to a reallocation of pollution across countries, and puts pressure on the environment (for a survey, see MABEY and MCNALLY, 1999). However, there is a consensus that the effect should not be viewed as causal when conditioning on other factors such as economic growth. Hence, what we know is that MNE activity raises economic prosperity and global output and demand, but that, conditional on that output and demand, MNE production is no more conducive to pollution or environmental damage than national firm activity. In fact, since MNEs may access a broad pool of technological practices across host countries and are generally more productive than local producers, they typically reduce environmental damage after conditioning on the level of output. Overall, the evidence of a positive relationship between global economic growth, multinational activity and global levels of pollution leads to the yet unresolved question of how to trade off economic prosperity with environmental protection, and to what extent. The solution to this question is particularly difficult since the preferences differ between developed economies (which tend to put a greater weight on environmental protection) and developing as well as transition economies (which claim the right to grow and to catch up to the levels of per-capita income and consumption in developed countries).

\section{Fiscal implications of hosting MNEs}

There is considerable evidence that cross-country tax rate differences incentivize MNEs to adopt tax avoidance strategies. As opposed to stand-alone firms, which reside in only one country, these firms can make use of such strategies by shifting profits to the country in which the tax treatment of profits is favorable. Consistent with this view, Egger, Eggert and Winner (2010) show that MNEs face a significantly lower tax burden than comparable firms that do not have access to international tax avoidance strategies. On average, foreign ownership reduces the tax burden by about 56\%. Mintz and Smart (2004) also find multidivisional firms to have an elasticity of taxable income with respect to tax rates of 4.9, compared with 2.3 for comparable firms that are constrained in shifting income 
through the use of a consolidated corporate tax base. ${ }^{7}$ These results are compatible with various mechanisms that MNEs use to save on taxes. MNEs can respond to taxes in a multi-faceted way - they may respond through real investment changes (at the intensive and extensive margin) as well as through strategic reporting behavior with respect to profits. The latter includes the strategic choice of prices for the internal exchange of goods and services among the subsidiaries of an MNE (transfer pricing) and choice of the volume and price of debt finance between subsidiaries. All three channels of tax avoidance appear to be used in practice. In the following, we briefly review some of the empirical evidence that is reported for each of the three channels of tax avoidance.

\subsection{Empirical estimates of MNE responses to taxes}

The different behavioral margins of MNEs will be influenced by different tax measures. This aspect is of importance for the identification of tax effects on different margins of firm behavior, such as the location choice of firms, their investment behavior and their use of transfer pricing and internal debt-shifting mechanisms. Theoretical predictions of the effect of taxes on the location choice of firms depend on the effective average tax rate - a tax measure that relates the projected tax payment in a given country to the profit a firm will earn after having located in that country. This tax measure depends on the statutory tax rate, but also on tax deductibility provisions such as the depreciation allowances that a tax system grants to firms. In contrast, the investment decisions of a firm in a given country will be influenced by the tax treatment of the marginal investment unit, i.e. the investment that yields a net-of-tax return to the investor that is equal to the investor's opportunity costs. The tax burden for this marginal investment project is the effective marginal tax rate. This tax measure is also influenced by the statutory tax rate and the tax value of deductibility provisions, but it is only calculated for the marginal investment project and thereby neglects the tax treatment of infra-marginal investment projects. The statutory tax rate in turn determines the incentives to shift profit within multinational firms by means of transfer pricing or internal debt finance. All three tax measures appear to have evolved differently over recent decades. As reported by Devereux, GRIFFITH and KLEMm (2002), statutory tax rates fell significantly over the period 19822001, a period in which foreign exchange rules were liberalized in most OECD countries, making capital more mobile. Taken in isolation, this is consistent with the view that governments have competed more fiercely for mobile corporate tax bases. However, this trend has been accompanied by a fall in the generosity of

7 A consolidated corporate tax base aggregates all profits of subsidiaries in the MNE group and allocates them to the different countries in which the subsidiaries reside according to some pre-specified weights. These are intended to reflect the economic origin of the profits. The weights used to allocate profits might be based on employment, capital inputs or sales figures; see, for example, Kind, Midelfart and SchJELDERUP (2005). 
depreciation allowances. Combining the two observations for both the effective marginal and average tax rate shows that it is the effective average tax rate that decreased over that time period, while the effective marginal tax rates shows only a moderate decrease, if any.

\subsubsection{Extensive and intensive investment responses}

The literature on how investments by MNEs respond to corporate taxes has grown rapidly in recent years. ${ }^{8}$ The empirical studies differ widely with respect to data, the econometric technique and the tax measures used to identify the effect of corporate taxation on investments. For instance, the studies vary with respect to the unit in which investments are observed, ranging from firm-level to countrylevel measures of investment behavior. DE MooIJ and EDERVEen (2003) review 25 empirical studies and conclude that the mean value of tax-rate elasticity (semi-elasticity) of foreign direct investment is around -3.3. In DE MooIJ and EDERVEEN (2008), they extend this set of studies by six and, importantly, disentangle the effect of corporate taxes on the intensive and extensive margin of foreign direct investment. They report that the typical semi-elasticity of foreign direct investment with respect to the effective marginal tax rate is -4.0 , and with respect to the effective average tax rate it is -5.9 . When looking on the number of locations, they conclude that the elasticity with respect to the effective marginal tax rate is -1.3 , and with respect to the effective average tax rate it is -3.2 . These estimates suggest that the extensive margin of investment is more tax-sensitive than the intensive margin. Countries therefore may be more inclined to compete with respect to the effective average tax rate; a conclusion that is consistent with the evolution of corporate tax systems reported in Devereux, Griffith and KLEMm (2002).

The finding that taxes influence foreign direct investment might not necessarily imply that investments in subsidiaries of an MNE are substitutes in the sense that a rise in corporate taxes in one subsidiary's home country shifts investments to subsidiaries that are located in other countries. This reasoning tends to conform to the view that MNEs' worldwide investments are fixed due to resource constraints, for instance. Looking at foreign investments of US MNEs, DESAI, Foley and Hines $(2005,2009)$ show that there may be no substitution between capital stocks of divisions of an MNE, and that capital stocks might even turn out to be complements. This finding is interesting as it speaks to the general perception or even fear that domestic firms that become international engage in less domestic investments and hence employment. Higher taxes in one country may in fact generate a co-movement of investments within an MNE. BECKER and

8 See, for example, Hines (1999); Gresik (2001); Devereux (2007); and Feld and Heckemeyer (2008) for an overview. 
RIEDEL (2012) report that investments might be complements and relate the comovement to corporate tax rate changes. They show that a 10 percentage point increase in corporate taxes lowers capital stocks of affiliated divisions in foreign countries by $5.6 \%$. This result is consistent with the view that internal investment budgets might not be fixed but instead are responsive to government policy, and that the responsiveness might be related to internal productivity changes through managerial incentive problems or the use of MNE-wide input factors (Nielsen, Raimondos-Møller and Schjelderup, 2010; Koethenbuerger and Stimmelmayr, 2013). The negative investment effect reported in Becker and RIEDEL (2012) is shown to neutralize a significant fraction of the otherwise prevailing tax competition externality, i.e. the effect of a higher tax on tax revenues in other locations of the MNE. Note, the tax revenue externality depends on reported profits and thus also reflects tax avoidance behavior through transfer pricing, for instance. Although investments go down, reported profits in other non-tax-raising locations of the MNE might still increase.

Besides choosing the location and volume of investments, MNEs might also strategically locate their headquarters in order to reduce the MNE-wide tax burden. Incentives to do so will be related to two aspects of the corporate tax system. First, host countries of the headquarters might operate a worldwide income tax system, as the United States does. This implies that when profits are repatriated from a subsidiary to the headquarters, the income is subject to the host country's corporate tax. For instance, the highest tax on repatriated profits in the United States is $30 \%$, which is high compared to the tax treatment of its subsidiaries in low-tax countries such as Ireland. Even if the MNE is able to fully credit the tax burden that already lies on the repatriated profit stream against the home country's taxes, the repatriation decision might still involve non-negligible additional tax payments (AltShuler and Grubert, 2003). Some host countries instead exempt repatriated profits from taxation, which makes them a preferable choice for the location of the MNE headquarters.

A second reason is related to the use of so-called "controlled foreign company" (CFC) rules. These rules allow the host country to tax the profits of a subsidiary even though the profits are not repatriated. In many cases, CFC rules allow passive income to be taxed immediately upon realization in the host country. Active income might also be taxed upon realization, provided the source tax rate at which this income is taxed at the subsidiary level falls below a pre-specified level. These rules limit an MNE's ability to defer taxes (in case the host country uses a worldwide income tax system) and to finance investments. For instance, Desai and Hines (2002) report that the pattern of US corporate inversion (switches in the locations of headquarters) supports the view that these firms try to reduce tax payments in the United States. Voget (2011) looks at the role of 
taxes in the choice of location of the headquarters of merging firms, and finds that the decision is tax-sensitive. An increase in the repatriation tax rate by 10 percentage points increases the share of relocating firms by 2.2 percentage points.

\subsubsection{Transfer pricing}

The strategic choice of the location of headquarters and MNE subsidiaries establishes an MNE-specific nexus of tax systems that the MNE can use to reduce its overall tax obligation. The basic idea is to report high profits in low-tax jurisdictions and low profits in high-tax jurisdictions. Two instruments that can be used in this regard are transfer pricing and internal debt financing within the MNE group. Transfer pricing might be used in the context of the internal trade of physical inputs or the internal trade in services, such as the use of licenses. These tax avoidance strategies become most attractive in environments in which the input or service under consideration has some unique element that makes it difficult for third parties (such as tax authorities in high-tax countries) to verify whether the price used for the internal trade in goods and service is justified based on economic grounds, or has been adjusted in order to shift profits to low-tax countries. The use of patents to shift profits is one example where tax-induced transfer pricing cannot be identified by comparing the transactions with those between unrelated parties, as required by the OECD guidelines on transfer pricing (OECD, 2010). Licenses are unique by construction and royalty payments from subsidiaries in high-tax jurisdictions to patent holders in low-tax jurisdictions are frequently observed in practice, with highly publicized examples including Google and Amazon.

The decision to use patents to save on taxes involves two stages. The first concerns the location of the patent (i.e. which entity is the owner of the patent) and the second concerns the determination of the royalty payment. As to the first choice, the lower a subsidiary's tax rate relative to the tax rate of other subsidiaries of the MNE group, the higher the amount of intangible assets located at that subsidiary (DISCHINGER and RIEDEL, 2010). Related evidence is reported in KARKINSKY and Riedel (2011) and GrifFith, Miller, and O'Connell (2014). Both exploit data on patent applications by European MNEs to analyze whether corporate taxes influence the location decision for patents. Consistent with tax-optimizing MNE choices, they find that taxes exert a negative effect on the number of patent applications. For US MNEs, Grubert and Slemrod (1998) and Desai, Foley and HiNEs (2006) show that US MNEs with high investments in intangible assets are more likely to establish a subsidiary in a tax haven. This observation is consistent with a tax-induced incentive to establish tax haven operations simply in order to allocate intangible assets to low-tax countries and to report royalty payments received from other subsidiaries as income of the tax haven operation. 
Several empirical studies address the second choice, that is, the volume of transfer pricing within MNEs. Compared to the empirical identification of the tax sensitivity of investments, the relevant tax measure that guides transfer-pricing incentives is easily observable. However, in contrast to investment data, data on transfer prices are rarely available to researchers. Instead, the typical approach taken in the literature is to estimate the effect of statutory tax rate differentials on measures of profitability, reflecting the idea that high levels of transfer pricing will increase the reported profitability of subsidiaries in low-tax countries and reduce the reported profitability of subsidiaries in high-tax countries. DE MooIJ (2005) reviews some of the empirical studies and concludes that the average tax rate (semi-)elasticity for MNEs is around -1.2 - a one percentage point increase in the corporate tax rate lowers corporate profitability by $1.2 \%$.

As reported by DE MoOIJ (2005), the semi-elasticity estimates vary greatly across studies, possibly reflecting different data quality and the countries involved. HuIZINGA and LAEvEN (2008) similarly report varying elasticity estimates for transfer pricing for European MNEs. On average, they find a semi-elasticity (with regards to the top statutory tax rate) of -1.3 , roughly consistent with the average elasticity value reported by DE MooIJ (2005). HuIZINGA and LAEVEN's estimates of the semi-elasticity for different European countries range from -0.51 to -2.92 . For Belgium and the Netherlands, for instance, the estimate is around -2.8 , while for Austria it is -1.07 .

DHARMAPALA (2014) summarizes the more recent literature on profit shifting. His assessment of the literature is that early estimates of the profit-shifting elasticity are far higher than those obtained in more recent studies. He concludes that one of the explanations for the downward trend in empirical estimates might be that data quality has improved over time and now allows for computing more accurate estimates of the profit-shifting elasticity.

\subsubsection{Internal debt shifting}

As mentioned above, the empirical strategy for identifying transfer pricing involves a comparison of the profitability of subsidiaries. Profitability differentials across subsidiaries may be related transfer pricing, but they may also reflect the use of financial transactions that yield tax savings to the MNE. The idea here is that subsidiaries in low-tax countries serve as financial centers for the MNE and give out loans to other subsidiaries in high-tax countries. Since interest payments are tax deductible, the internal provision of debt finance shifts profits to low-tax countries. In general, the tax-induced preference for debt finance also applies to non-MNEs, but differs from it in important ways. The use of debt finance by nonMNEs implies that loans are received by external institutions and that the threat 
of illiquidity limits the amount of debt that firms can take on the balance sheet. With MNEs, the creditor is internal to the MNE group and the threat to liquidate the debtor is not so strong. Incentives to engage in debt finance might therefore be more pronounced compared to non-MNEs. Early measurements of the tax-induced preference for debt finance include GRAHAM, LEMMON and SCHALlHEIM (1998) and GoRDON and LEE (2001). They find that a one percentage point increase in the corporate tax rate increases the debt/asset ratio by $0.43 \%$ and $0.36 \%$, respectively. Looking more directly at the internal use of debt finance in European MNEs, HuIZINGA, LAEVEN and NiCODÈmE (2008) conclude that ignoring the internal use of debt finance leads to an underestimation of the effect of taxes on debt policy by $25 \%$. Using US data, Desai, Foley and Hines (2004) find a tax elasticity of the debt/asset ratio of 0.28 . The estimated elasticity of external borrowing is found to be 0.19 , while the elasticity for internal borrowing is 0.35 . These results are consistent with the view that internal borrowing is more tax-sensitive than external borrowing. Egger, Keuschnigg, Merlo and Wamser (2014) look at internal borrowing decisions and the role of taxes involved. Controlling for other non-tax factors that determine the amount of internal borrowing within German MNE groups, they report that a one percentage point increase in the statutory tax rate in the host country is associated with a 0.92 percentage point increase in the ratio of internal debt to assets of the borrowing affiliate.

The empirical literature shows the importance of corporate taxes for MNE decisions. Based on the estimates, it can be concluded that the most tax-sensitive decision margin of MNEs is the profit-shifting margin. It involves limited real adjustments in the MNE, such as changes in the production structure or adjustments in the geographical organization of research and development activities. The recent Base Erosion and Profit Shifting (BEPS) initiative by the OECD addresses the disconnection between the decisions on where to generate value added and where to report profits. It aims to initiate policy measures in OECD member states that ensure that taxable profits are reported in the country where the value added is actually generated.

\subsection{Swiss corporate tax reform discussions}

The OECD's BEPS project, as well as the EU Commission's action plan to combat tax avoidance and tax evasion, have significantly increased the pressure on Switzerland in recent years. The focal point of the criticism is that the Swiss tax system allows for some discriminatory taxation. In general, corporations are subject to taxation at the federal, cantonal and municipal levels. The average GDPweighted corporate tax rate is $23 \%$ and the tax base that is subject to the corporate tax was around CHF50 billion in 2010 (EFD, 2013). A special tax regime exists 
for certain types of firms, such as holdings, management companies and so-called mixed companies. A prerequisite for these firms to be eligible for the special tax regime is that their Swiss operation be limited to administrative tasks for foreign subsidiaries, i.e. the holding and management of shares of foreign firms. Business activities in Switzerland should play a minor role. These firms are subject to the regular federal corporate tax, but enjoy a lower tax treatment at the cantonal level. The cantonal tax rate depends on the canton and type of firm, and varies between $0.5 \%$ and $4 \%$.

Criticism from abroad is related to the fact that domestic Swiss firms are taxed at a higher rate than international firms, which are more mobile. The firms that are eligible for the special tax regime might be in charge of central headquarter functions and own critical assets of MNEs. Transfer pricing and internal debt shifting might thus be two important tax instruments that these firms use to transfer profits to Switzerland.

Given the criticism, a reform of the Swiss corporate tax system has been given fresh impetus. Corporate Tax Reform III is intended to bring the current tax system in line with the EU and OECD action plans, whilst maintaining Switzerland's attractiveness as a tax location. The basic idea of the reform is to replace the explicit discrimination of corporate taxation with a system in which the corporate tax treatment is uniform for international and domestic firms, but to introduce elements into the tax system that are of particular value to international firms. The key element of the reform discussion is the introduction of a licence box whereby income - for example, from patents, licences and trademarks - is taxed at a reduced rate. Licence boxes are used in various countries, including Belgium, the UK and the Netherlands. The licence box can be used by all firms in Switzerland, and is thus non-discriminatory, but it is mostly international firms that own patents, for instance. These firms can use transfer-pricing techniques to locale profits in its Swiss operation. The incentives to use the licence box will depend on its exact definition, i.e. the income streams that qualify for the preferred tax treatment. While a narrowly defined licence box might be restricted to incomes that are explicitly due to the sale of licences, a broadly defined licence box might also include some form of presumed licence income (income that is part of the general income stream, for example, and can be argued to be related to the existence of a trademark). ${ }^{9}$

9 The reform proposals that are being discussed in Switzerland also include the introduction of an allowance for corporate equity (ACE). The tax system provides a tax subsidy on the costs of equity-financed investments and, in general, is intended to ensure neutrality of financial choices (given that the costs of debt finance are tax deductible for corporations) and neutrality of investment choices (DEVEREUX and FREEMAN, 1991). These effects might not be realized in general. See Keuschnigg and Ribi (2013) and Koethenbuerger and Stimmelmayr (2014) on the role of financial constraints and corporate governance issues in this context. 
Different margins of MNE behavior will be affected by the change in the tax system. Physical investment responses at the intensive margin will be limited, given the requirement that business activities in Switzerland should play a minor role. Since the potential switch to a licence box should preserve incentives to locate profits in Switzerland, the important behavioral margin appears to be the transfer-pricing margin.

Chatagny, Koethenbuerger and Stimmelmayr (2014) assess the implications of different variants of a licence box solution through the use of a computable general equilibrium model. To quantify the incentives to engage in transfer pricing, they use transfer-pricing elasticity values ranging from -0.4 to -1.1 . A value of -0.4 corresponds to the elasticity value HUIZINGA and LAEvEN (2008) find for Austria, while a value of -1.1 corresponds to that of Belgium and the Netherlands. The results of these investigations show that if the special tax regime were to be abolished without the introduction of a licence box, around $88 \%$ of the tax base of special companies - which include holdings, management companies and mixed companies - will leave Switzerland. This corresponds to a loss of tax revenue from special companies of around $67 \%$, or just under CHF3.5 billion. This level of tax loss could be largely contained by the introduction of a licence box. For instance, the introduction of a narrowly defined licence box in parallel with the reduction of the (cantonal) rates of taxes on earnings by four percentage points could reduce the erosion of the tax base of special companies to just under $40 \%$. However, the additional tax revenue generated by the abolition of the special tax regime and the taxation of income that does not qualify for the licence box is more than cancelled out by the deadweight effect and lower tax revenue at the cantonal level. This means that reduced tax revenue cannot be avoided completely.

If a broadly defined licence box were to implemented in conjunction with a reduction in the (cantonal) rate of taxes on earnings by four percentage points, the erosion of the tax base of special companies would be reduced accordingly, and could be limited to around $23 \%$. However, in such a scenario the deadweight effect of ordinarily taxed companies would be significantly stronger, with the result that - along with the reduced tax revenue at the cantonal level - the costs of financing the broadly defined licence box would end up being significantly higher.

The introduction of a licence box in Switzerland would level the playing field visà-vis other European countries that have already introduced such a tax savings instrument (Belgium and the Netherlands introduced one in 2007, followed by Luxembourg in 2008 and the United Kingdom in 2013). The introduction of such a scheme was accompanied by a surge in patent applications in these countries, 
which is a prerequisite for shifting licence income to them. As simulated by Griffith Miller, and O'Connell (2014), the implications for tax revenues may appear more sobering. Tax revenues fell after the introduction of the licence box, reflecting the fact that the statutory tax rates that apply to licence income in these countries are significantly lower than the regular rates of corporate taxation. The simulation results may be interpreted as a lower bound for tax revenues, since the simulation exercise assumes a constant amount of tax income per patent, both before and after the introduction of the licence box. However, transfer pricing is highly responsive to tax rate differentials across countries, and a significantly lower statutory tax rate for licence income presumably increases the amount of taxable profits that is shifted per patent to these countries.

\section{Conclusion}

The main purpose of this paper is to review the literature on multinational enterprises (MNEs) regarding the main drivers of and consequences of their existence. Clearly, in the short run, some of the drivers are unrelated to economic policy, while others are rooted in economic policy choices (e.g. the tariff regime, membership of preferential trade agreements, services trade provisions, and tax environment including the existence and nature of double taxation treaties). In the long run, the role of economic policy may be even more important, as it may have repercussions for productivity, factor prices, and even the accumulation of factors (e.g. through skill formation and schooling) and market size (through fertility choices, migration and economic growth).

While providing a cursory overview of these fundamentals, the paper puts emphasis on the fiscal implications of hosting MNEs, and in particular on these implications in view of the current tax environment in Switzerland.

\section{References}

Aitken, Brian, Ann Harrison, and Robert E. Lipsey (1996), Wages and foreign ownership: a comparative study of Mexico, Venezuela, and the United States, Journal of International Economics 40 (3-4), pp. 345-371.

Almeida, Rita (2007), The labor market effects of foreign owned firms, Journal of International Economics 72 (1), pp. 75-96.

Altshuler, Rosanne and Harry Grubert (2003), Repatriation Taxes, Repatriation Strategies and Multinational Financial Policy, Journal of Public Economics 87 (1), pp. 73-107. 
Baldwin, Richard E. and Daria TAgLioni (2012), Gravity chains: Estimating bilateral trade flows when parts and components trade is important, unpublished manuscript, University of Geneva.

Baltagi, Badi H., Peter H. Egger and Michaela Kesina (2014), Firm-level Productivity Spillovers in China's Chemical Industry: A Spatial Hausman-Taylor Approach, Journal of Applied Econometrics, forthcoming.

Barba Navaretti, Giorgio and Davide Castellani (2004), Investments abroad and performance at home: evidence from Italian multinationals, CEPR Discussion Paper No. 4284, London.

Becker, Sascha O. and Marc-Andreas Muendler (2008), The effect of FDI on job security, The B.E. Journal of Economic Analysis \& Policy 8 (1), pp. $1-46$.

Becker, Johannes and NADine Riedel (2012), Cross-border tax effects on affiliate investment - evidence from European multinationals, European Economic Review 56 (3), pp. 436-450.

Bergstrand, Jeffrey H. and Peter H. Egger (2010), A general equilibrium theory for estimating gravity equations of bilateral FDI, final goods trade and intermediate goods trade, in: Brakman, Steven and Peter van Bergeijk (editors), The Gravity Model in International Trade: Advances and Applications, Cambridge University Press, New York.

Bergstrand, Jeffrey H., Peter H. Egger and Mario Larch (2010), The new expats: economic determinants of bilateral expatriate, FDI, and international trade flows, unpublished manuscript, University of Notre Dame.

Bloom, Nicholas, Raffaella Sadun and John Van Reenen (2012), Americans do I.T. better: US multinationals and the productivity miracle, American Economic Review 102 (1), pp. 167-201.

Bloom, Nicholas, Mark Schankerman, and John van Reenen (2013), Identifying technology spillovers and product market rivalry, Econometrica 81 (4), pp. 1347-1393.

Braconier, Henrik and Karolina Ekholm (2000), Swedish multinationals and competition from high- and low-wage locations, Review of International Economics 8 (3), pp. 448-461.

BrainARD, LAEL S. and DAVID RIKer (2001), Are US multinationals exporting US jobs?, in GREENAWAY, DAVID and Douglas R. Nelson (editors), Globalization and Labour Markets, Vol. 2, Elgar, Cheltenham, UK and Northhampton, MA, pp. 410-426.

Budd, John W., Josef Konings, and Matthew J. Slaughter (2005), International profit sharing in multinational firms, Review of Economics and Statistics 87 (1), pp. 73-84.

Burstein, Ariel, Christopher Kurz and Linda Tesar (2008), Trade, production sharing, and the international transmission of business cycles, Journal of Monetary Economics 55 (4), pp. 775-795. 
Chatagny, Florian, Mario Koethenbuerger and Michael Stimmelmayr (2014), Introducing an IP-licence box in Switzerland: Quantifying the effects, mimeo, KOF.

CiPE, Center for International Private Enterprise (2009), Corporate Governance: The Intersection of Public and Private Reform, Washington, DC.

DE Moois, RuUd A. (2005), Will corporate income taxation survive? De Economist 153, pp. 277-301.

De Mooij, Ruud A. and SJef Ederveen (2003), Taxation and foreign direct investment: A synthesis of empirical research, International Tax and Public Finance 10 (6), pp. 673-693.

De Mooij, Ruud A. and Sjef Ederveen (2008), Corporate tax elasticities: a reader's guide to empirical findings, Oxford Review of Economic Policy 24 (4), pp. 680-697.

Desai, Minir A. and James R. Hines (2002), Expectations and expatriations: tracing the causes and consequences of corporate inversions, National Tax Journal 55 (3), pp. 409-440.

Desai, Mihir A., C. Fritz Foley, and James R. Hines (2004), A multinational perspective on capital structure choice and internal capital markets, Journal of Finance 59 (6), pp. 2451-2487.

Desai, Minir A., C. Fritz Foley, and James R. Hines (2005), Foreign direct investment and the domestic capital stock, American Economic Review 95 (2), pp. 33-38.

Desai, Minir A., C. Fritz Foley, and James R. Hines (2006), The demand for tax haven operations, Journal of Public Economics 90 (3), pp. 513- 531.

Desai, Minir A., C. Fritz Foley, and James R. Hines (2009), Domestic effects of the foreign activities of US multinationals, American Economic Journal: Economic Policy 1 (1), pp. 181-203.

Devereux, Michael P. (2007), The impact of taxation on the location of capital, firms and profit: a survey of empirical evidence, Oxford University Centre for Business Taxation Working Paper No. 0702.

Devereux, Michael P. and Harold Freeman (1991), A general neutral profits tax, Fiscal Studies 12 (3), pp. 1-15.

Devereux, Michael P., Rachel Griffith and Alexander Klemm (2002), Corporate income tax reforms and international tax competition, Economic Policy 35, pp. 451-495.

Dharmapala, Dhammika (2014), What do We Know about base erosion AND PROFIT SHIFTING? A REVIEW OF THE EMPIRICAL LITERATURE, CESifo Working Paper Series 4612, Munich.

Dischinger, Matthias and NAdine Riedel (2011), Corporate taxes and the location of intangible assets within multinational firms, Journal of Public Economics 95 (7-8), pp. 691-707. 
Dobbelaere, Sabien (2004), Ownership, firm size and rent sharing in Bulgaria, Labour Economics 11 (2), pp. 165-89.

Egger, Hartmut and Udo Kreickemeier (2013), Why foreign ownership may be good for you, International Economic Review 54 (2), pp. 693-716.

Egger, Peter H. and Michael Pfaffermayr (2005), Trade, multinational sales, and FDI in a three-factors model, Review of International Economics 13 (4), pp. 659-675.

Egger, Peter H. and Tobias Seidel (2013), Corporate taxes and intra-firm trade, European Economic Review 63, pp. 225-242.

Egger, Peter H. and Hannes Winner (2005), On the short run and long run effects of corruption on foreign direct investment, European Journal of Political Economy 21 (4), pp. 932-952.

Egger, Peter H. and Hannes Winner (2006), How corruption influences FDI: a panel data study, Economic Development and Cultural Change 54 (2), pp. 459-486.

Egger, Peter H., Wolfgang Eggert and Hannes Winner (2010), Saving taxes through foreign plant ownership, Journal of International Economics 81 (1), pp. 99-108.

Egger, Peter H., Christian Keuschnigg, Valeria Merlo and Georg WamsER (2014), Corporate taxes and internal borrowing within multinational firms, American Economic Journal: Economic Policy 6 (2), pp. 54-93.

EFD, EIdGENÖSSISCHES FINANZDEPARTEMENT (2013), Massnahmen zur Stärkung der steuerlichen Wettbewerbsfähigkeit (Unternehmensteuerreform III).

Ekholm, Karolina, Ricard Forslid, and James R. MARkusen (2007), Export-platform foreign direct investment, Journal of the European Economic Association 5 (4), pp. 776-795.

Feenstra, Robert C. and Gordon H. Hanson (1999), The impact of outsourcing and high-technology capital on wages: estimates for the United States, 1979-1990, The Quarterly Journal of Economics 114 (3), pp. 907-940.

Feld, Lars P. and Jost H. Heckemeyer (2011), FDI and taxation: A meta study, Journal of Economic Surveys 25 (2), pp. 233-272.

Girma, Sourafel and Holger Görg (2007), Evaluating the foreign ownership wage premium using a difference-in-differences matching approach, Journal of International Economics 72 (1), pp. 97-112.

Girma, Sourafel, David Greenaway, and Katherine Wakelin (2001), Who benefits from foreign direct investment in the UK? Scottish Journal of Political Economy 48 (2), pp. 119-33.

Globerman, Steven, John C. Ries and Ilan Vertinsky (1994), The economic performance of foreign affiliates in Canada, Canadian Journal of Economics 27 (1), pp. 143-56. 
Görg, Holger, Eric Strobl and Frank Walsh (2007), Why do foreign-owned firms pay more? The role of on-the-job training, Review of World Economics 143 93), pp. 464-82.

Gordon, Roger H. and Young LeE (2001), Do taxes affect corporate debt policy? Evidence from U.S. corporate tax return data, Journal of Public Economics 82 (2), pp.195-224.

Graham, John R., Michael L. Lemmon and James S. Schallheim (1998), Debt, leases, taxes, and the endogeneity of corporate tax status, Journal of Finance 53 (1), pp. 131-162.

Gresik, Thomas (2001), The taxing task of taxing transnationals, Journal of Economic Literature 39 (3), pp. 800-838.

GRIFFITH, RACHEL and HELEN SIMPSON (2004), Characteristics offoreign-owned firms in British manufacturing, in: BLUNDELl, RICHARD, DAVID CARD and Richard Freeman (eds), Creating a Premier League Economy, Chicago, Chicago University Press, Chicago, IL.

Griffith, Rachel, Helen Miller, and Martin O'Connell (2014), Ownership of intellectual property and corporate taxation, Journal of Public Economics 112 , pp. 12-23.

Grubert, Harry and Joel Slemrod (1998), The effect of taxes on investment and income shifting to Puerto Rico ${ }_{2}$ Review of Economics and Statistics 80 (3), pp. 365-373.

HARrison, Ann and JASON SCORSE (2009), Do foreign-owned firms pay more? Evidence from the Indonesian manufacturing sector, in: Kanbur, Ravi and Jan Svejnar (editors), Labor Markets and Economic Development, Routledge, London pp. 319-340.

Helpman, Elhanan, Marc J. Melitz and Stephen R. Yeaple (2004), Export versus FDI with heterogeneous firms, American Economic Review 94 (1), pp. 300-316.

Hines, JAMES R. JR. (1999), Lessons from behavioral responses to international taxation, National Tax Journal 52 (2), pp. 305-322.

Hsu, Chin-Chiang, Jyun-Yi Wu and Ruey Yau (2011), Foreign direct investment and business cycle co-movements: the panel data evidence, Journal of Macroeconomics 33 (4), pp. 770-783.

Hu, Albert G. Z., Gary H. Jefferson and Qian Jinchang (2005), R\&D and technology transfer: firm-level evidence from Chinese industry, The Review of Economics and Statistics 87 (4), pp. 780-786.

HuIZINGA, HARRY and LUC LAEven (2008), International profit shifting within multinationals: A multi-country perspective, Journal of Public Economics 92 (5-6), pp. 1164-1182.

Huizinga, Harry, Luc Laeven and Gaetan Nicodème (2008), Capital structure and international debt-shifting, Journal of Financial Economics 88 (1), pp. $80-118$. 
JANSEN, W. Jos and Ad StokmAn (2006), International rent sharing and domestic labour markets: a macroeconomic analysis, Review of World Economics (Weltwirtschaftliches Archiv) 142 (4), pp. 792-813.

Karkinsky, Tom and NAdine Riedel (2012), Corporate taxation and the choice of patent location within multinational firms, Journal of International Economics 88 (1), pp. 176-185.

Keller, Wolfgang and Stephen R. Yeaple (2009), Multinational enterprises, international trade, and productivity growth: firm-Level evidence from the United States, The Review of Economics and Statistics 91 (4), pp. 821-831.

Keuschnigg, Christian and Evelyn Ribi (2013), Profit taxes and financing constraints, International Tax and Public Finance 20 (5), pp. 808-826.

Kind, Hans, Karen Helene Midelfart and Guttorm Schjelderup (2005), Corporate tax systems, multinational enterprises, and economic integration, Journal of International Economics 65 (2), pp. 507-521.

Kleinert, Joern, Julien Martin and Farid Toubal (2014), The few leading the many: foreign affiliates and business cycle comovement, American Economic Journal: Macroeconomics, forthcoming.

Koethenbuerger, Marko and Michael Stimmelmayr (2013), Taxing multinationals in the presence of internal capital markets, CESifo Working Paper No. 4533, Munich.

Koethenbuerger, Marko and Michael Stimmelmayr (2014), Corporate deductibility provisions and managerial incentives, Journal of Public Economics 111 (C), pp. 120-130.

Konings, Jozef (2000), The effects of direct foreign investment on domestic firms: Evidence from firm level panel data in emerging economies, CEPR Discussion Paper No. 2586, London.

Kravis, Irving B. and Robert E. LiPSEy (1988), The effect of multinational firms' foreign operations on their domestic employment, NBER Working Paper No. 2760.

Lipsey, Robert E. and Fredrik Sjöholm (2004), Foreign direct investment, education and wages in Indonesian manufacturing, Journal of Development Economics 73 (1), pp. 415-22.

LööF, HANs (2009), Multinational enterprises and innovation: firm level evidence on spillover via R\&D collaboration, Journal of Evolutionary Economics 19 (1), pp. 41-71.

Mabey, Nick and Richard McNally (1999), Foreign direct investment and the environment: from pollution havens to sustainable development, WWF-UK Report.

Malchow-Møller, Nikolaj, James R. Markusen and Bertel Schjerning (2007), Foreign firms, domestic wages, NBER Working Paper No. 13001, Cambridge, MA. 
MARKuSEn, JAMES R. (2002), Multinational Firms and the Theory of International Trade, MIT Press.

Mintz, Jack and Michael Smart (2004), Income shifting, investment, and tax competition: theory and evidence from provincial taxation in Canada, Journal of Public Economics 88 (6), pp. 1149-1168.

Muendler, Marc-Andreas and Sascha O. Becker (2010), Margins of multinational labor substitution, American Economic Review 100 (5), pp. 19992030.

Nielsen, Søren B., Pascalis Raimondos-Møller and Guttorm Schjelderup (2010), Company taxation and tax spillovers: Separate accounting versus formula apportionment, European Economic Review 54 (1), pp. 121-132.

OECD (2010), Transfer Pricing Guidelines, Paris.

Pfaffermayr, Michael (2001), Employment in domestic plants and foreign affiliates: A note on the elasticity of substitution, Review of World Economics (Weltwirtschaftliches Archiv) 137 (2), pp. 347-364.

Pierre, Norbert (2011), Foreign direct investment, rule of law and corruption.

Slaughter, Matthew J. (2000), Production transfer within multinational enterprises and American wages, Journal of International Economics 50 (2), 449-472.

SMARZYNSKa JaVORCIK, BEATA (2004), Does foreign direct investment increase the productivity of domestic firms? In search of spillovers through backward linkages, American Economic Review 94 (3), pp. 605-627.

Swenson, Deborah L. and Huiya Chen (2014), Multinational exposure and the quality of new Chinese exports, Oxford Bulletin of Economics and Statistics $76(1), 41-66$.

Te Velde, Dirk W. and Oliver Morrissey (2003), Do workers in Africa get a wage premium if employed in firms owned by foreigners? Journal of African Economies 12 (1), pp. 41-73.

Voget, Johannes (2011), Relocation of headquarters and international taxation, Journal of Public Economics 95 (9-10), pp. 1067-1081. 